\title{
Lactobacillus equigenerosi sp. nov., a coccoid species isolated from faeces of thoroughbred racehorses
}

\author{
Correspondence \\ Akihito Endo \\ pegaman@hotmail.co.jp
}

\author{
Akihito Endo, ${ }^{1,2}$ Stefan Roos, ${ }^{3}$ Eiichi Satoh, ${ }^{4}$ Hidetoshi Morita ${ }^{5}$ \\ and Sanae Okada ${ }^{1,4}$ \\ ${ }^{1}$ NODAI Culture Collection Center, Tokyo University of Agriculture, 1-1-1 Sakuragaoka, Setagaya, \\ Tokyo 156-8502, Japan \\ ${ }^{2}$ Division of Pharmacognosy, Phytochemistry and Narcotics, National Institute of Health Sciences, \\ Ministry of Health, Labour and Welfare, 1-18-1 Kamiyoga, Setagaya, Tokyo 158-8501, Japan \\ ${ }^{3}$ Department of Microbiology, Swedish University of Agricultural Sciences, Box 7025, \\ SE-750 07 Uppsala, Sweden \\ ${ }^{4}$ Department of Applied Biology and Chemistry, Tokyo University of Agriculture, 1-1-1 \\ Sakuragaoka, Setagaya, Tokyo 156-8502, Japan \\ ${ }^{5}$ School of Veterinary Medicine, Azabu University, 1-17-71 Fuchinobe, Sagamihara, Kanagawa \\ 229-8501, Japan
}

\begin{abstract}
Two strains of lactic acid bacteria were isolated from faeces of two actively racing thoroughbred horses. The isolates formed a subcluster in the Lactobacillus reuteri phylogenetic group, closely related to Lactobacillus fermentum, L. gastricus, L. ingluviei and L. mucosae, by phylogenetic analysis based on 16S rRNA gene sequences. Levels of DNA-DNA relatedness revealed that the isolates belonged to the same taxon and were genetically separated from their phylogenetic relatives. Biochemical and physiological characteristics also distinguished the isolates from their phylogenetic relatives. The isolates produced spherical or oval cells, and tetrad-like cells were rarely seen. To the best of our knowledge, this is the first report of this morphological characteristic within the genus Lactobacillus. Thus, the isolates represent an atypical novel species of the genus Lactobacillus, for which the name Lactobacillus equigenerosi sp. nov. is proposed. The type strain is NRIC $0697^{\top}\left(=\mathrm{JCM} 14505^{\top}=\mathrm{DSM} 18793^{\top}\right)$.
\end{abstract}

The gastrointestinal tracts of animals harbour complex microbiota, and lactic acid bacteria are common members of the microbiota of many animals. As lactic acid bacteria have been reported to have several health-promoting effects on host animals (Ouwehand et al., 2002), the microbiota of the organisms in faeces and/or gastrointestinal contents have been actively studied for many animals (Brashears et al., 2003; Casey et al., 2004; Walter et al., 2001).

During a study of lactic acid bacteria inhabiting the gastrointestinal tract of thoroughbred racehorses, 35 strains of lactic acid bacteria were isolated from faeces of six thoroughbreds. Thirty of the isolates were identified as

The GenBank/EMBL/DDBJ accession numbers for the 16S rRNA gene sequences of strains NRIC 0696 and $\mathrm{NRIC} 0697^{\top}$ are respectively AB288049 and AB288050.

16S rRNA gene sequence-based maximum-likelihood and maximumparsimony trees are available as supplementary material with the online version of this paper.
Lactobacillus equi, L. johnsonii, L. kitasatonis, L. mucosae, L. salivarius, Streptococcus bovis, S. equinus or Weissella confusa, and the other five strains could not be identified (unpublished data). Two of the five strains were phylogenetic relatives of Lactobacillus gastricus, one was a phylogenetic relative of Lactobacillus salivarius and the other two belonged to the Streptococcus phylogenetic cluster. The phylogenetic relative of $L$. salivarius was recently classified within a novel Lactobacillus species, Lactobacillus hayakitensis (Morita et al., 2007). This paper deals with the taxonomic study of the two phylogenetic relatives of L. gastricus.

Faecal samples were collected from six actively racing thoroughbred horses at the Miho or Ritto Training Center in Ibaraki or Shiga prefecture of Japan in 2003, and the faeces were immediately brought to our laboratory under anaerobic conditions by using anaerobic jars (GasPak System; BBL). Strains NRIC 0696 and NRIC $0697^{\mathrm{T}}$ were isolated from faeces of different thoroughbreds collected at the Ritto Training Center by using LBS agar (BBL) under 
anaerobic conditions in anaerobic jars. After isolation, they were maintained on MRS agar (Oxoid) containing $5.0 \mathrm{~g}$ calcium carbonate $1^{-1}$. L. gastricus DSM $16045^{\mathrm{T}}$ was obtained from the DSMZ and the strain was used as a reference strain in the present study. The reference strain was also maintained on MRS agar.

16S rRNA gene sequences of the two isolates were determined by methods described previously (Endo \& Okada, 2005). The closest recognized relatives of the isolates were determined by performing DataBase searches, and sequences of closely related species were retrieved from DDBJ. Multiple alignments of the sequences were carried out with the program CLUSTAL_X, version 1.18 (Thompson et al., 1997). Distance matrices for the aligned sequences were calculated by using the two-parameter method of Kimura (1980). The neighbour-joining method was used to construct a phylogenetic tree (Saitou \& Nei, 1987). The robustness of individual branches was estimated by bootstrapping with 1000 replicates (Felsenstein, 1985). Phylogenetic trees were also constructed by using the maximum-likelihood (Cavalli-Sforza \& Edwards, 1967) and maximum-parsimony (Kluge \& Farris, 1969) methods with PHYLIP version 3.65 as described previously (Endo \& Okada, 2006). The determined 16S rRNA gene sequences of the isolates were compared with each other, and the sequence of NRIC $0697^{\mathrm{T}}$ was used to search for sequence similarity with DataBase. Approximately $1450 \mathrm{bp}$ of the $16 \mathrm{~S}$ rRNA gene sequences of the isolates and related species were used for constructing phylogenetic trees. The sequence similarity between NRIC 0696 and NRIC $0697^{\mathrm{T}}$ was $99.9 \%$. The highest sequence similarity of NRIC $0697^{\mathrm{T}}$ to the type strains of known species of lactic acid bacteria was found with L. gastricus, L. mucosae, L. ingluviei and $L$. fermentum (97.9, 95.8, 95.2 and 93.4\%, respectively). The DataBase search also showed that the partial sequence of NRIC $0697^{\mathrm{T}}$ was identical to the sequence of the predominant DNA (GenBank accession no. AB250240) derived from faeces of thoroughbreds by using Lactobacillus-group-specific denaturing gradient gel electrophoresis analysis in our other study (Endo et al., 2007). This probably shows that the isolates represent one of the predominant Lactobacillus species in faeces of thoroughbreds. The isolates formed a subcluster with Lactobacillus fermentum, L. gastricus, Lactobacillus ingluviei and $L$. mucosae in the Lactobacillus reuteri phylogenetic group (Schleifer \& Ludwig, 1995; Hammes \& Hertel, 2006) on the basis of neighbour-joining analysis (Fig. 1). Identical tree topologies were obtained by using the maximum-parsimony and maximum-likelihood analysis (see Supplementary Figs S1 and S2 in IJSEM Online). $L$. gastricus, L. ingluviei and L. mucosae were originally isolated from the gastrointestinal contents of animals (Roos et al., 2000, 2005; Baele et al., 2003) and L. fermentum has been isolated from various environmental samples including animal faeces (Dellaglio et al., 2004). This suggests that the major habitat of members of this subcluster is the animal gastrointestinal tract.

Levels of DNA-DNA relatedness between the isolates and L. gastricus DSM $16045^{\mathrm{T}}$ and the $\mathrm{G}+\mathrm{C}$ contents of the isolates were determined by methods described previously (Endo \& Okada, 2006). Extraction and isolation of bacterial DNAs were performed by the method of Marmur (1961) as modified by Ezaki et al. (1983). Strains of $L$. fermentum, L. ingluviei and $L$. mucosae were not used for the determination of DNA-DNA relatedness because the sequence similarities between the isolates and the type strains of these three species were lower than the recommended value for species differentiation described by Stackebrandt \& Goebel (1994). Recently, a revised recommended value for species differentiation was suggested, at 98.7-99\% (Stackebrandt \& Ebers, 2006). The isolates showed a high level of DNA-DNA relatedness

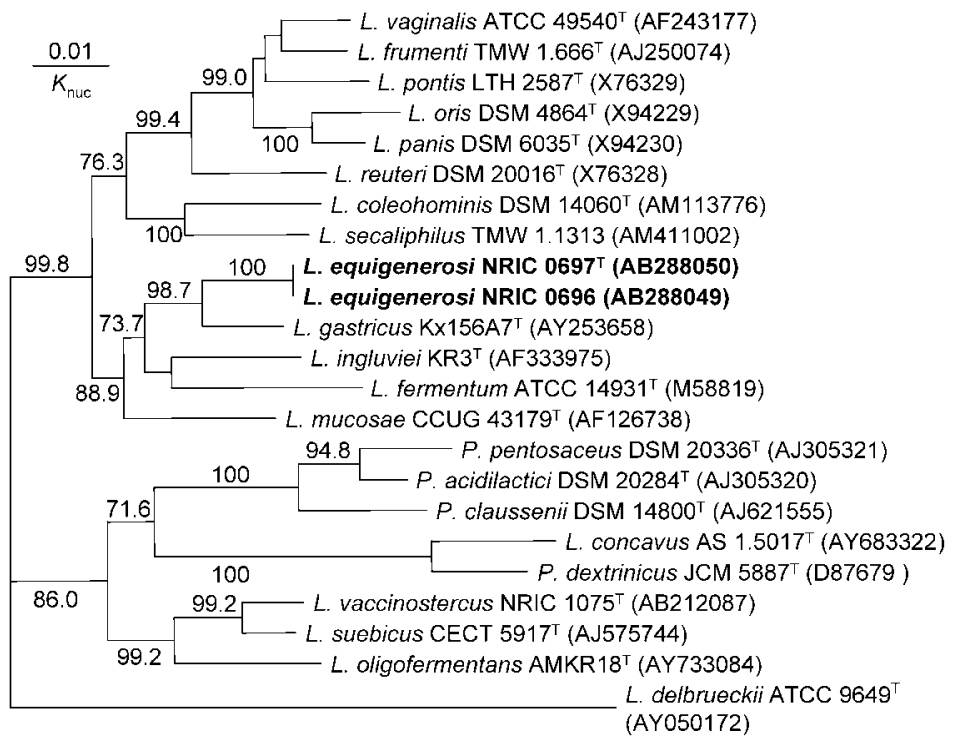

Fig. 1. Phylogenetic relationships of strains NRIC 0696 and NRIC 0697 ${ }^{\top}$ (L. equigenerosi sp. nov.) to related species based on $16 \mathrm{~S}$ rRNA gene sequences. The tree was constructed by the neighbour-joining method. $L$. delbrueckii ATCC $9649^{\top}$ was used as an outgroup. Bootstrap percentages above $70 \%$ are given at branching points. Bar, evolutionary distance $\left(K_{\text {nuc }}\right)$ of 0.01 . 
Table 1. Differential characteristics between $L$. equigenerosi sp. nov. (strains NRIC 0696 and NRIC 0697 ${ }^{\top}$ ) and closely related species

Species: 1, L. equigenerosi sp. nov.; 2, L. gastricus (unless indicated, data from Roos et al., 2005); 3, L. fermentum (Dellaglio et al., 2004); 4, L. ingluviei (Baele et al., 2003); 5, L. mucosae (Roos et al., 2000). +, Positive; -, negative; $v$, variable; $\mathrm{W}$, weakly positive.

\begin{tabular}{|lccccc|}
\hline Characteristic & $\mathbf{1}$ & $\mathbf{2}$ & $\mathbf{3}$ & $\mathbf{4}$ & $\mathbf{5}$ \\
\hline Cell morphology & Round & Round $^{*}$ & Rod & Rod & Rod \\
Acid from: & & & & & \\
D-Xylose & + & - & $\mathrm{V}$ & + & $\mathrm{V}$ \\
D-Fructose & $\mathrm{W}$ & + & + & + & - \\
Cellobiose & - & + & $\mathrm{V}$ & - & - \\
Melibiose & + & + & + & - & $\mathrm{V}$ \\
D-Salicin & - & + & - & - & - \\
Trehalose & - & + & $\mathrm{V}$ & - & - \\
Growth at $15 / 45{ }^{\circ} \mathrm{C}$ & $-/+$ & $-/-$ & $+/+$ & $-/+$ & $-/+$ \\
G + C content & 42 & 41.3 & $52-54$ & 49 & 46.5 \\
$($ mol\%) & & & & & \\
\hline
\end{tabular}

${ }^{\star}$ Determined in the present study.

(93\%). Therefore, we concluded that the isolates belonged to the same taxon. In contrast, the isolates showed low levels of DNA-DNA relatedness to L. gastricus DSM $16045^{\mathrm{T}}$ $(18-23 \%)$. The $\mathrm{G}+\mathrm{C}$ contents of the isolates were $42 \mathrm{~mol} \%$.

Biochemical and physiological characteristics of the isolates were determined by methods described previously (Endo \& Okada, 2005). The detailed characteristics of the isolates are given in the species description, and the characteristics were compared with those of phylogenetic relatives $L$. fermentum, L. gastricus, L. ingluviei and L. mucosae (Table 1). The isolates were obligately heterofermentative lactic acid bacteria, and produced DL-lactic acid, carbon dioxide and ethanol or acetic acid from D-glucose. The isolates were distinguished from L. gastricus by their acid production patterns from carbohydrates and growth at $45{ }^{\circ} \mathrm{C}$ (Table 1). Furthermore, values of DNA G+C content of the isolates were very different from those of L. fermentum, L. ingluviei and L. mucosae (Table 1).

Morphological characteristics of NRIC $0697^{\mathrm{T}}$ and $L$. gastricus DSM $16045^{\mathrm{T}}$ were determined by using a scanning electron microscope (SEM). The type strains were cultured for 1 to 2 days in MRS broth at $37{ }^{\circ} \mathrm{C}$ under anaerobic conditions. After culturing, cells were washed with $0.2 \mathrm{M}$ phosphate buffer ( $\mathrm{pH} 7.0$ ), fixed with $2 \%$ glutaraldehyde for $2 \mathrm{~h}$ at $4{ }^{\circ} \mathrm{C}$, post-fixed with $1 \% \mathrm{OsO}_{4}$ for $3 \mathrm{~h}$ at $4{ }^{\circ} \mathrm{C}$, dehydrated with a series of increasing ethanol concentrations $(70,80,90$ and $95 \%$ and twice at $100 \%$, for $15 \mathrm{~min}$ each) and soaked in 3-methyl butyl acetate for 1 day. The prepared cells were subsequently critical-point-dried in a critical-point drying unit (model HCP-2; Hitachi), sputtered with $\mathrm{Pt} / \mathrm{Pd}$ (model E-102; Hitachi) and observed with an SEM (model S-4000; Hitachi). Scanning electron micrographs of NRIC $0697^{\mathrm{T}}$ and L. gastricus DSM $16045^{\mathrm{T}}$ are shown in Fig. 2. The micrographs showed that the cells of both strains were spherical or oval cocci and occurred singly or in pairs. Tetrad-like coccoid cells were rarely seen for either strain. L. gastricus has been reported to produce rod-shaped cells (Roos et al., 2005), but we were unable to observe rod-shaped cells for either type strain in various growth phases and/or in various media (data not shown). We then determined the morphological characteristics of
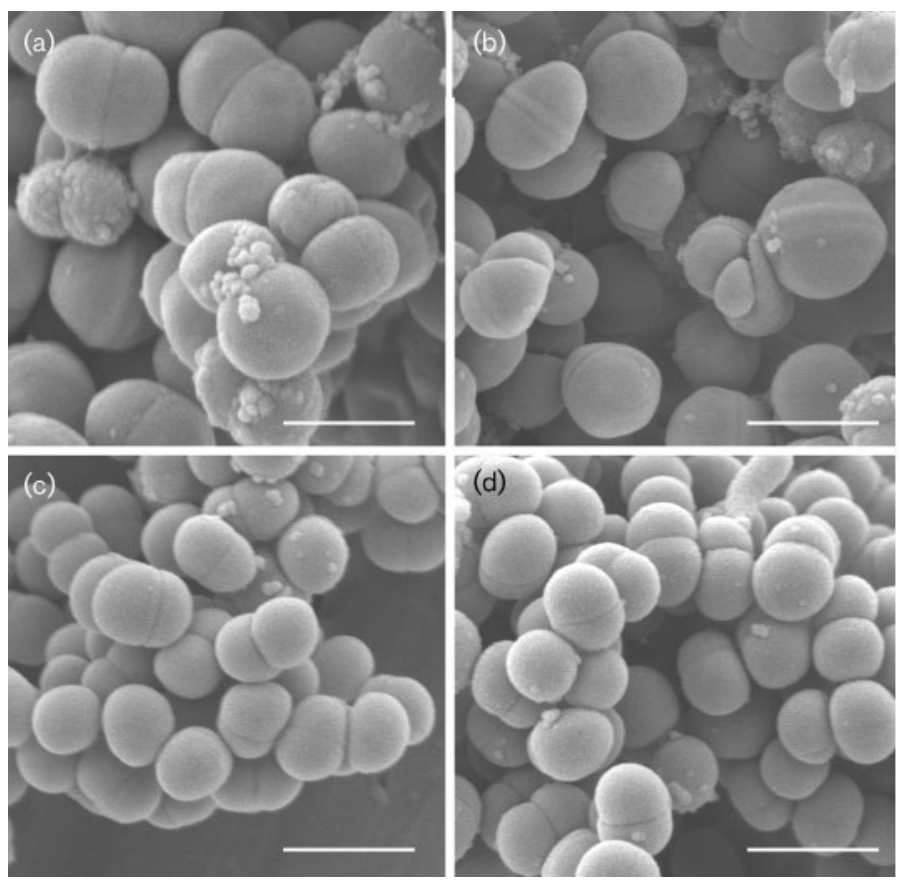

Fig. 2. Scanning electron micrographs of cells of $L$. equigenerosi NRIC $0697^{\top}(a, b)$ and $L$. gastricus DSM $16045^{\top}$ (c, d). Bars, $1 \mu \mathrm{m}$. 
the original type strain of L. gastricus, $\mathrm{Kx} 156 \mathrm{~A} 7^{\mathrm{T}}$, preserved at the Swedish University of Agricultural Sciences. In our analysis, this strain formed coccoid cells that occurred in pairs or in tetrads, but not rod-shaped cells. Therefore, we concluded that $L$. gastricus is a coccus. The species of the genus Lactobacillus are well known as producing rodshaped cells (Rogosa, 1974; Hammes \& Vogel, 1996), but the phylogenetic cluster of the genus Lactobacillus comprises bacilli with cocci, which are the tetrad-forming cocci in the genus Pediococcus (Collins et al., 1991; Schleifer \& Ludwig, 1995). Almost all members of the genus Pediococcus formed a subcluster within the Lactobacillus cluster (Liu et al., 2006) but, exceptionally, Pediococcus dextrinicus did not belong to the Pediococcus subcluster and formed a subcluster with Lactobacillus species (Liu et al., 2006; Tong \& Dong, 2005). As P. dextrinicus was a tetradforming coccus (Garvie, 1986), the species was classified as a member of the genus Pediococcus (Simpson \& Taguchi, 1996; Garvie, 1986). However, more recently, classification of lactic acid bacteria at the genus level has been based on phylogenetic position using 16S rRNA gene sequences (Schleifer \& Ludwig, 1995) rather than morphological characteristics. The genus Weissella, one of the genera of lactic acid bacteria, also comprises bacilli and cocci (Collins et al., 1993). As mentioned above, as the new isolates and $L$. gastricus formed a subcluster with Lactobacillus species by phylogenetic analysis (Fig. 1), the isolates and L. gastricus should be regarded as coccoid species in the genus Lactobacillus based on the current classification method of lactic acid bacteria (Schleifer \& Ludwig, 1995). With application of this classification method, $P$. dextrinicus should also be a member of the genus Lactobacillus rather than the genus Pediococcus, although this is not discussed further in the present study.

Based on the data provided, the isolates can be assigned as members of the genus Lactobacillus by their phylogenetic position, but physiological and biochemical characteristics and levels of DNA-DNA relatedness distinguished the isolates from their phylogenetic relatives. Moreover, morphological characteristics demonstrated that the isolates represented an atypical species in the genus Lactobacillus. Thus, the isolates represent a novel species, for which the name Lactobacillus equigenerosi sp. nov. is proposed. In addition, as the morphological characteristics of $L$. gastricus do not conform to the original description of the species (Roos et al., 2005), an emended description of Lactobacillus gastricus is presented below.

\section{Description of Lactobacillus equigenerosi sp. nov.}

Lactobacillus equigenerosi (e'qui.ge.ne.ro'si. L. n. equus a horse; L. adj. generosus of noble birth, well-bred; N.L. gen. n. equigenerosi of a thoroughbred horse).

Cells are Gram-positive, non-motile and spherical or oval cocci measuring $0.5-0.8 \times 0.8-1.5 \mu \mathrm{m}$. Cells usually occur singly or in pairs, and tetrad-like cells are uncommon.
Facultatively anaerobic and catalase-negative. Growth in broth is enhanced under anaerobic conditions. Colonies are not formed under aerobic conditions but are formed under anaerobic conditions. Colonies on MRS agar under anaerobic conditions are beige, smooth and approximately 1-2 $\mathrm{mm}$ in diameter after incubation for 2 days at $37^{\circ} \mathrm{C}$. Obligately heterofermentative and produces DL-lactic acid, carbon dioxide and ethanol or acetic acid from D-glucose. Nitrate is not reduced. Acid is produced from D-glucose, Dxylose, maltose, melibiose and sucrose and is produced weakly from D-ribose and D-fructose, but acid is not produced from L-rhamnose, cellobiose, D-salicin, trehalose, melezitose, D-mannitol, D-sorbitol or starch. Acid production from $\mathrm{L}$-arabinose, $\mathrm{D}$-galactose, lactose and raffinose is strain-dependent. Cells grow at $30-45{ }^{\circ} \mathrm{C}$ and grow slowly at $25{ }^{\circ} \mathrm{C}$, but not at 20 or $50{ }^{\circ} \mathrm{C}$. Both known strains grow at $\mathrm{pH} 4.0$ but not at $\mathrm{pH}$ 3.5. Growth is observed in MRS broth containing $2.5 \%(\mathrm{w} / \mathrm{v}) \mathrm{NaCl}$ but not $5.0 \%(\mathrm{w} / \mathrm{v})$ $\mathrm{NaCl}$. The DNA G+C content of both known strains is $42 \mathrm{~mol} \%$.

The type strain is NRIC $0697^{\mathrm{T}}\left(=\mathrm{JCM} 14505^{\mathrm{T}}=\mathrm{DSM}\right.$ $\left.18793^{\mathrm{T}}\right)$. Strains NRIC $0697^{\mathrm{T}}$ and NRIC 0696 were isolated from faeces of thoroughbred racehorses collected at the Ritto Training Center in Shiga prefecture, Japan, in 2003.

\section{Emended description of Lactobacillus gastricus Roos et al. 2005}

Lactobacillus gastricus (gas'tri.cus. N.L. masc. adj. gastricus from Gr. adj. gastrikos of the stomach).

The description of L. gastricus is as given in detail by Roos et al. (2005) with the following change. Cells are spherical or oval cocci measuring $0.6-0.8 \times 1.0-2.0 \mu \mathrm{m}$. Cells usually occur singly or in pairs, and tetrad-like cells are uncommon. The type strain is $\mathrm{Kx} 156 \mathrm{~A} 7^{\mathrm{T}}\left(=\mathrm{LMG} 22113^{\mathrm{T}}\right.$ $=$ DSM $16045^{\mathrm{T}}=$ CCUG $48454^{\mathrm{T}}$ ).

\section{Acknowledgements}

We thank all concerned parties of the Seishi, Yuasa and Setoguchi stables of the Japan Racing Association and the Muneishi stable of the Kochi Racing Association, as well as M. Iida (Chiyoda Farm), M. Matsumoto (Japan Race Horse Registry), K. Shimamura (KK Bestsellers) and M. Nagayama (Kochi Racing Association) for their help with collection of horse faecal samples. Thanks are also due to J. P. Euzéby (Société de Bactériologie Systématique et Vétérinaire and École Nationale Vétérinaire de Toulouse) for advice on the naming of the novel species, Y. Yaguchi (Electron Microscope Center, Tokyo University of Agriculture) for advice about procedures for SEM observation and C. Obata (NODAI Culture Collection Center) for technical assistance.

\section{References}

Baele, M., Vancanneyt, M., Devriese, L. A., Lefebvre, K., Swings, J. \& Haesebrouck, F. (2003). Lactobacillus ingluviei sp. nov., isolated from the intestinal tract of pigeons. Int J Syst Evol Microbiol 53, 133-136. 
Brashears, M. M., Jaroni, D. \& Trimble, J. (2003). Isolation, selection, and characterization of lactic acid bacteria for a competitive exclusion product to reduce shedding of Escherichia coli O157:H7 in cattle. J Food Prot 66, 355-363.

Casey, P. G., Casey, G. D., Gardiner, G. E., Tangney, M., Stanton, C., Ross, R. P., Hill, C. \& Fitzgerald, G. F. (2004). Isolation and characterization of anti-Salmonella lactic acid bacteria from the porcine gastrointestinal tract. Lett Appl Microbiol 39, 431-438.

Cavalli-Sforza, L. L. \& Edwards, A. W. F. (1967). Phylogenetic analysis models and estimation procedures. Am J Hum Genet 19, 233-257.

Collins, M. D., Rodrigues, U. M., Ash, C., Aguirre, M., Farrow, J. A. E., Martinez-Murcia, A., Philips, B. A., Williams, A. M. \& Wallbanks, S. (1991). Phylogenetic analysis of the genus Lactobacillus and related lactic acid bacteria as determined by reverse transcriptase sequencing of $16 \mathrm{~S}$ rRNA. FEMS Microbiol Lett 77, 5-12.

Collins, M. D., Samelis, J., Metaxopoulos, J. \& Wallbanks, S. (1993). Taxonomic studies on some leuconostoc-like organisms from fermented sausages: description of a new genus Weissella for the Leuconostoc paramesenteroides group of species. J Appl Microbiol 75, 595-603.

Dellaglio, F., Torriani, S. \& Felis, G. E. (2004). Reclassification of Lactobacillus cellobiosus Rogosa et al. 1953 as a later synonym of Lactobacillus fermentum Beijerinck 1901. Int J Syst Evol Microbiol 54, 809-812.

Endo, A. \& Okada, S. (2005). Lactobacillus satsumensis sp. nov., isolated from mashes of shochu, a traditional Japanese distilled spirit made from fermented rice and other starchy materials. Int J Syst Evol Microbiol 55, 83-85.

Endo, A. \& Okada, S. (2006). Oenococcus kitaharae sp. nov., a novel non-acidophilic and non-malolactic fermenting oenococcus isolated from a composting distilled shochu residue. Int J Syst Evol Microbiol 56, 2345-2348.

Endo, A., Okada, S. \& Morita, H. (2007). Molecular profiling of Lactobacillus, Streptococcus, and Bifidobacterium species in feces of active racehorses. J Gen Appl Microbiol 53, 191-200.

Ezaki, T., Yamamoto, N., Ninomiya, K., Suzuki, S. \& Yabuuchi, E. (1983). Transfer of Peptococcus indolicus, Peptococcus asaccharolyticus, Peptococcus prevotii, and Peptococcus magnus to the genus Peptostreptococcus and proposal of Peptostreptococcus tetradius sp. nov. Int J Syst Bacteriol 33, 683-698.

Felsenstein, J. (1985). Confidence limits on phylogenies: an approach using the bootstrap. Evolution 39, 783-791.

Garvie, E. I. (1986). Genus Pediococcus Claussen 1903. In Bergey's Manual of Systematic Bacteriology, vol. 2, pp. 1075-1079. Edited by P. H. A. Sneath, N. S. Mair, M. E. Sharpe \& J. G. Holt. Baltimore: Williams \& Wilkins.

Hammes, W. P. \& Hertel, C. (2006). The genera Lactobacillus and Carnobacterium. In The Prokaryotes, 3rd edn, vol. 4, pp. 320-403. Edited by M. Dworkin, S. Falkow, E. Rosenberg, K. H. Schleifer \& E. Stackebrandt. New York: Springer.

Hammes, W. P. \& Vogel, R. F. (1996). The genus Lactobacillus. In The Lactic Acid Bacteria, vol. 2, The Genera of Lactic Acid Bacteria, pp. 1954. Edited by B. J. B. Wood \& W. H. Holzapfel. London: Blackie.
Kimura, M. (1980). A simple method for estimating evolutionary rates of base substitutions through comparative studies of nucleotide sequences. J Mol Evol 16, 111-120.

Kluge, A. G. \& Farris, F. S. (1969). Quantitative phyletics and the evolution of anurans. Syst Zool 18, 1-32.

Liu, L., Zhang, B., Tong, H. \& Dong, X. (2006). Pediococcus ethanolidurans sp. nov., isolated from the walls of a distilled-spiritfermenting cellar. Int J Syst Evol Microbiol 56, 2405-2408.

Marmur, J. (1961). A procedure for the isolation of deoxyribonucleic acid from microorganisms. J Mol Biol 3, 208-218.

Morita, H., Shiratori, M., Murakami, M., Takami, H., Kato, Y., Endo, A., Nakajima, F., Takagi, M., Akita, H. \& other authors (2007). Lactobacillus hayakitensis sp. nov., isolated from intestines of healthy thoroughbreds. Int J Syst Evol Microbiol 57, 2836-2839.

Ouwehand, A. C., Salminen, S. \& Isolauri, E. (2002). Probiotics: an overview of beneficial effects. Antonie van Leeuwenhoek 82, 279-289.

Rogosa, M. (1974). Genus Lactobacillus. In Bergey's Manual of Determinative Bacteriology, 8th edn, pp. 576-593. Edited by R. E. Buchanan \& N. E. Gibbons. Baltimore: Williams \& Wilkins.

Roos, S., Karner, F., Axelsson, L. \& Jonsson, H. (2000). Lactobacillus mucosae sp. nov., a new species with in vitro mucus-binding activity isolated from pig intestine. Int J Syst Evol Microbiol 50, 251-258.

Roos, S., Engstrand, L. \& Jonsson, H. (2005). Lactobacillus gastricus sp. nov., Lactobacillus antri sp. nov., Lactobacillus kalixensis sp. nov. and Lactobacillus ultunensis sp. nov., isolated from human stomach mucosa. Int J Syst Evol Microbiol 55, 77-82.

Saitou, N. \& Nei, M. (1987). The neighbor-joining method: a new method for reconstructing phylogenetic trees. Mol Biol Evol 4, 406-425.

Schleifer, K. H. \& Ludwig, W. (1995). Phylogeny of the genus Lactobacillus and related genera. Syst Appl Microbiol 18, 461-467.

Simpson, W. J. \& Taguchi, H. (1996). The genus Pediococcus with notes on the genera Tetragenococcus and Aerococcus. In The Lactic Acid Bacteria, vol. 2, The Genera of Lactic Acid Bacteria, pp. 125-172. Edited by B. J. B. Wood \& W. H. Holzapfel. London: Blackie.

Stackebrandt, E. \& Ebers, J. (2006). Taxonomic parameters revisited: tarnished gold standards. Microbiol Today 33, 152-155.

Stackebrandt, E. \& Goebel, B. M. (1994). Taxonomic note: a place for DNA-DNA reassociation and $16 \mathrm{~S}$ rRNA sequence analysis in the present species definition in bacteriology. Int J Syst Bacteriol 44, 846-849.

Thompson, J. D., Gibson, T. J., Plewniak, F., Jeanmougin, F. \& Higgins, D. G. (1997). The CLUSTAL_X windows interface: flexible strategies for multiple sequence alignment aided by quality analysis tools. Nucleic Acids Res 25, 4876-4882.

Tong, H. \& Dong, X. (2005). Lactobacillus concavus sp. nov., isolated from the walls of a distilled spirit fermenting cellar in China. Int J Syst Evol Microbiol 55, 2199-2202.

Walter, J., Hertel, C., Tannock, G. W., Lis, C. M., Munro, K. \& Hammes, W. P. (2001). Detection of Lactobacillus, Pediococcus, Leuconostoc, and Weissella species in human faeces by using group-specific PCR primers and denaturing gradient gel electrophoresis. Appl Environ Microbiol 67, 2578-2585. 